\title{
The Synthesis and Evaluation of a Novel Inhibitor DN for Carbon Dioxide Corrosion
}

\author{
Qingwang Liu, Tong Zhang, Jigang Wang, Zhenzhong Fan, Ao Sun, Dong Cheng \\ EOR Key Laboratory of the Ministry of Education, Northeast Petroleum University, Daqing, China \\ Email: LIUQINGWANG@163.com, 648553814@qq.com, wangjigang9999@163.com, fanzhenzhong@163.com, \\ sunsunaoao@126.com, 277134741@qq.com
}

Received 17 September 2014; revised 7 October 2014; accepted 17 October 2014

Copyright (C) 2014 by authors and Scientific Research Publishing Inc.

This work is licensed under the Creative Commons Attribution International License (CC BY). http://creativecommons.org/licenses/by/4.0/

(c) (i) Open Access

\begin{abstract}
During the oil and gas wells exploitation and transportation, carbon dioxide corrosion is one of main reasons for the corrosion of metallic materials. So the methods of preventing and reducing carbon dioxide corrosion have become a widely focused problem. The foreign and domestic practices and experiences show that as an economic, effective and versatile metal corrosion control method, corrosion inhibitor protection technology is suitable for application in oil and gas transportation system. This paper, through the indoor experiment with benzyl chloride, using quinoline as raw materials, synthesizes a kind of quinoline quaternary ammonium salt. The obtained product benzyl chloride quinoline compounded with OP-10 and ethanol to get a novel inhibitor DN for carbon dioxide corrosion, and to evaluate its performance.
\end{abstract}

\section{Keywords}

Carbon Dioxide, Corrosion Inhibitor, Synthesis Method, Performance Evolution

\section{Introduction}

In the oil field development, gathering and transportation process, carbon dioxide corrosion problem widely exist. In the proper pressure and humidity conditions, carbon dioxide will produce carbonic acid and it can corrode the oil casing and cement severely. All kinds of metal pipes and equipment will suffer from fierce corrosion and erosion; eventually it will shorten the working life of the pipelines and equipments and cause great economic loss [1]. So the methods of preventing and reducing carbon dioxide corrosion have become a widely focused problem.

The foreign and domestic practices and experiences show that as an economic, simple dosing equipment, easy operation and versatile metal corrosion control method, corrosion inhibitor protection technology is suitable for

How to cite this paper: Liu, Q.W., Zhang, T., Wang, J.G., Fan, Z.Z., Sun, A. and Cheng, D. (2014) The Synthesis and Evaluation of a Novel Inhibitor DN for Carbon Dioxide Corrosion. Open Journal of Composite Materials, 4, 215-219.

http://dx.doi.org/10.4236/ojcm.2014.44023 
application in oil and gas transportation system. Now the development of oil and gas well corrosion inhibitor for carbon dioxide corrosion resistance has become more and more important and it can bring huge economic benefits for the oil industry. This experiment will synthesis a novel inhibitor DN for carbon dioxide corrosion with the method of fractional steps and evaluates the performance of the inhibitor.

\section{Experimental}

\subsection{The Experimental Materials and Methods}

\subsubsection{Experimental Instruments}

Electric treater(HK/ZX-100); four-necked reaction flask; electric heating-jacket (ZNHW-10,000 ml); electronic balance; beakers (JA5003) and so on.

\subsubsection{Experimental Materials}

Quinoline, analytical grade; OP-10, analytical grade; Benzyl chloride, analytical grade; Ethanol, analytical grade; Epoxy chloropropane, analytical grade; Acrylic acid, analytical grade.

\subsubsection{The Synthesis Methods of Corrosion Inhibitor}

$1 \mathrm{~mol}$ of quinoline was added into a four-necked reaction flask equipped with a stirrer, reflux condenser and thermometer, and then heated to $90^{\circ} \mathrm{C} .1 \mathrm{~mol}$ benzyl chloride was dropped into the quinoline solution and the mixture was heated to $140^{\circ} \mathrm{C}$ and kept at that temperature for $2 \mathrm{~h}$. After the reaction, the solution was cooled down to the room temperature within $30 \mathrm{~min}$. The precipitate was collected and compounded with $127.5 \mathrm{~g}$ OP-10 and $255 \mathrm{~g}$ ethanol after the solution was cooled down to room temperature naturally, and then the quinoline quaternary ammonium salt corrosion inhibitor was obtained, the first reaction mechanism is as follows:

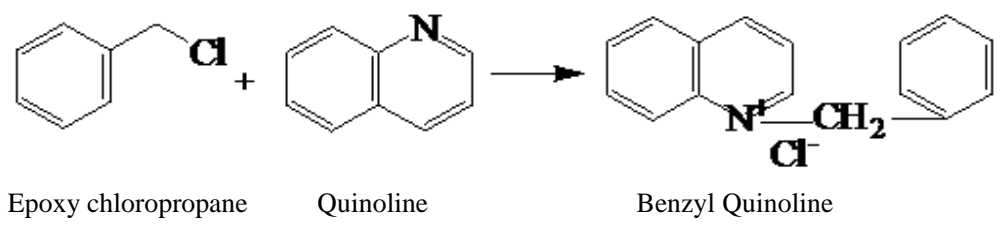

\subsection{Results and Discussion}

\subsubsection{The Influencing Factors of Corrosion Inhibitor DN Performance}

In this test, the performance of the corrosion inhibitor DN can be determined by the type and amount of initiator, the reaction mole ratio of quinoline and epoxy chloropropane and the reaction temperature, reaction time and other factors by the control. Thus, for the synthesis of carbon dioxide inhibitor must to study the impact of various factors on corrosion inhibition properties through repeated experiments, And ultimately determine the optimal synthesis conditions to obtain desirable properties of the product.

\subsubsection{The Effect of the Reaction Mole Ratio of Epoxy Chloropropane and Quinoline}

Greater effect of the reaction mole ratio of epoxy chloropropane and quinoline on the performance of corrosion inhibitor, in order to examine the effect of the reaction mole ratio on the performance of corrosion inhibitor, all the reaction conditions are not changed, the corrosion inhibition performance of corrosion inhibitor DN as shown in Table 1.

From the above Table 1, it can be seen that when the reaction mole ratio of epoxy chloropropane and quinoline is $1: 1$, the corrosion rate is the lowest $(0.1008 \mathrm{~mm} / \mathrm{a})$ and the inhibition efficiency is the highest (97.5\%), so determine the optimal ratio of 1:1.

\subsubsection{The Effect of Reaction Time}

Changes the reaction time have a great impact on the performance of corrosion inhibitor. In order to examine the effect of the time on the performance of corrosion inhibitor, all the other reaction conditions are not changed except reaction mole ratio of epoxy chloropropane and quinoline is 1:1, the performance of corrosion inhibitor DN as shown in Table 2. 
From the above Table 2, it can be seen that when the reaction time is 3 hours, the corrosion rate is the lowest $(0.0953 \mathrm{~mm} / \mathrm{a})$ and the inhibition efficiency is the highest $(97.6 \%)$, the inhibition effect is the best, so determine the optimal reaction time is 3 hours.

\subsubsection{The Effect of Reaction Temperature}

Changes the reaction temperature have a great impact on the performance of corrosion inhibitor. In order to examine the effect of the reaction time on the performance of corrosion inhibitor, under conditions of 1:1 mole ratio of epoxy chloropropane and quinoline, the reaction time is 4 hours, changing the reaction temperature, the performance of corrosion inhibitor DN as shown in Table 3.

As can be seen from the Table 3, the reaction temperature is significantly influence the reaction rate and the degree of corrosion inhibitor, thus affecting the performance of the corrosion inhibitor. The synthesis temperature too low or too high are both not conducive to the reaction. When the reaction temperature is $130^{\circ} \mathrm{C}$, the corrosion rate is the lowest $(0.1104 \mathrm{~mm} / \mathrm{a})$ and the inhibition efficiency is the highest $(95.1 \%)$, the inhibition effect is the best, so determine the optimal reaction temperature is $130^{\circ} \mathrm{C}$.

\section{Evaluation of Corrosion Inhibitor Performance}

\subsection{The Evaluation of Thermal Stability}

According to the experimental method of thermal stability evaluation methods of corrosion inhibitor of oil field [2], put three copies of corrosion inhibitor DN in different temperature and curing for 24 hours, the concentration of corrosion inhibitor is $1 \%$, then observe what happened of this solution, the thermal stability of corrosion inhibitor DN as shown in Table 4.

As can be seen from the Table 4, under the different temperature $30^{\circ} \mathrm{C}, 60^{\circ} \mathrm{C}$ and $90^{\circ} \mathrm{C}$, the corrosion inhibitor

Table 1. The effect of reaction mole ratio of epoxy chloropropane and quinoline on the performance of corrosion inhibitor DN.

\begin{tabular}{rccc}
\hline Reaction mole ratio & $1: 0.9$ & $1: 1.0$ & $1: 1.1$ \\
Corrosion rate mm/a & 0.1148 & 0.1008 & 0.1371 \\
Inhibition efficiency \% & 89.4 & 97.5 & 83.9 \\
\hline
\end{tabular}

Table 2. The effect of time on the on the performance of corrosion inhibitor DN.

\begin{tabular}{ccccc} 
Reaction time $\mathrm{h}$ & 3 & 4 & 5 \\
Corrosion rate $\mathrm{mm} / \mathrm{a}$ & 0.0953 & 0.1203 & 0.1012 \\
Inhibition efficiency $\%$ & 97.6 & 89.2 & 88.6 \\
\hline
\end{tabular}

Table 3. The effect of reaction temperature on the performance of corrosion inhibitor DN.

\begin{tabular}{cccc}
\hline Reaction temperature ${ }^{\circ} \mathrm{C}$ & 120 & 130 & 140 \\
Corrosion rate mm/a & 0.2107 & 0.1104 & 0.1649 \\
Inhibition efficiency $\%$ & 79.6 & 95.1 \\
\hline
\end{tabular}

Table 4. The evaluation of thermal stability of corrosion inhibitor DN.

\begin{tabular}{cc}
\hline Temperature ${ }^{\circ} \mathrm{C}$ & Phenomenon \\
30 & Aqueous solution homogeneous, no stratification, no precipitation \\
60 & Aqueous solution homogeneous, no stratification, no precipitation \\
90 & Aqueous solution homogeneous, no stratification, no precipitation \\
\hline
\end{tabular}


solution has no stratification, no precipitation and the solution aqueous homogeneous, all these phenomenon show that the thermal stability of corrosion inhibitor DN is good.

\subsection{The Evaluation of Water Solubility}

According to the experimental method of water solubility evaluation methods of corrosion inhibitor of oil field, put several copies of corrosion inhibitor of different concentrations in the thermostat, the concentrations of corrosion inhibitor solution are $200 \mathrm{mg} / \mathrm{L}, 1000 \mathrm{mg} / \mathrm{L}, 2000 \mathrm{mg} / \mathrm{L}, 5000 \mathrm{mg} / \mathrm{L}$ and 10,000 mg/L, adjust the thermostat to $30^{\circ} \mathrm{C}$. After 30 minutes and 24 hours, observe what happened of this solution then note it [2]. The water solubility of corrosion inhibitor DN as shown in Table 5 .

As can be seen from the Table 5, under $30^{\circ} \mathrm{C}$ and after 30 minutes and 24 hours, these five copies of corrosion inhibitor solution have no stratification, no precipitation and the solution aqueous homogeneous, the colour of the solution is dark red, all these phenomenon show that the corrosion inhibitor DN has good water solubility.

\subsection{The Evaluation of Compatibleness}

In development course of oil field, the single corrosion inhibitor can not be used.The corrosion inhibitor always be used with all kinds of different treatment agent such as demulsifying agent, scale inhibitor [3], bactericide and so on. If the corrosion inhibitor can take reaction with these treatment agents and give a precipitate or the other products, it can influencing the performance of the corrosion inhibitor directly, thus may affecting the development schedule of the oil field. Use the bactericide TQ-1 that usually used in oil field, scale inhibitor HEDP, clay stabilizer FL and demulsifying agent PC as the compatibility experiment. Measuring the scale inhibition rate by the methods that specified in the petroleum and natural gas industry standards SY/T5673. Measuring the bactericidal rate by the methods that specified in the petroleum and natural gas industry standards SY/T5890-93 and using the methods that specified in the petroleum and natural gas industry standards SY/T5273-2000 to measure the inhibition efficiency of corrosion inhibitor DN. The result of compatibleness as shown in Table 6 .

As the Table 6 shown, adding the different kinds of treatment agent in the corrosion inhibitor DN, the inhibition efficiency is better than ever before and various functions of the other treatment agent do not be changed. So the compatibleness of corrosion inhibitor DN with bactericide TQ-1, scale inhibitor HEDP, clay stabilizer FL and demulsifying agent PC is good.

\section{Summary}

1) The corrosion inhibitor DN is a kind of novel corrosion inhibitor that uses benzyl chloride and quinoline as the raw material, synthesis a kind of quinoline quaternary ammonium salt, then makes the product benzyl quinoline compound with ethanol and OP-10.

Table 5. The evaluation of water solubility of corrosion inhibitor DN.

\begin{tabular}{cccc}
\hline Concentration mg/L & 200 & 1000 & 2000 \\
\hline $30^{\circ} \mathrm{C} 30$ minutes & & Aqueous solution homogeneous, no stratification, no precipitation, dark red \\
$30^{\circ} \mathrm{C} 30$ hours & & Aqueous solution homogeneous, no stratification, no precipitation, dark red \\
\hline
\end{tabular}

Table 6. The evaluation of compatibleness of corrosion inhibitor DN.

\begin{tabular}{|c|c|c|c|c|c|}
\hline Treatment agent & $\mathrm{DN}$ & $\mathrm{DN}+\mathrm{PC}$ & $\mathrm{DC}+\mathrm{TQ}-1$ & $\mathrm{DC}+\mathrm{HEDP}$ & $\mathrm{DC}+\mathrm{FL}$ \\
\hline Added amount g/L & 10 & $10+1$ & $10+1$ & $10+1$ & $10+5$ \\
\hline Inhibition efficiency \% & 96.8 & 95.4 & 93.3 & 95.1 & 94.8 \\
\hline Dehydration rate \% & & 93.2 & & & \\
\hline Bactericidal rate \% & & & 99.6 & & \\
\hline Scale inhibition rate \% & & & & 97.1 & \\
\hline Expansivity \% & & & & & 5.43 \\
\hline
\end{tabular}


2) According to the large amounts of evaluation experiments of corrosion inhibitor performance, as the results shown, the thermal stability and water solubility of corrosion inhibitor DN are good and DN can compound with various treatment agents, enhancing the inhibition efficiency, the compatibleness of corrosion inhibitor DN is good.

\section{Acknowledgements}

The project is supported by PetroChina Innovation Foundation of Cationic Gemini Surfactant Property Evaluation and Oil Displacement Mechanism Study. Fund No.: 2013D-5006-0205

\section{References}

[1] Zhang, X.Y., Wang, F.P., He, Y.F. and Du, Y.L. (2001) Study of the Inhibition Mechanism of Imidazoline Amide on $\mathrm{CO}_{2}$ Corrosion of Armcoiron. Corrosion Science, 43, 1417-1431. http://dx.doi.org/10.1016/S0010-938X(00)00160-8

[2] Liang, L. (2010) Synthesis and Performance Evaluation of Quaternary Ammonium Salt Corrosion Inhibitor. Chemical Engineering, 38, 235-237.

[3] Crolet, J.L. (1994) Predicting $\mathrm{CO}_{2}$ Corrosion in Oil and Gas Industry. The Institute of Materials, London, 1. 
Scientific Research Publishing (SCIRP) is one of the largest Open Access journal publishers. It is currently publishing more than 200 open access, online, peer-reviewed journals covering a wide range of academic disciplines. SCIRP serves the worldwide academic communities and contributes to the progress and application of science with its publication.

Other selected journals from SCIRP are listed as below. Submit your manuscript to us via either submit@scirp.org or Online Submission Portal.
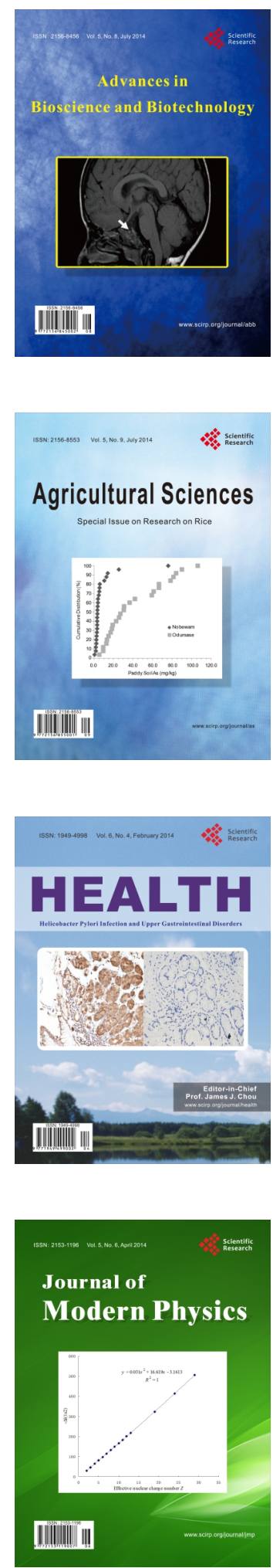
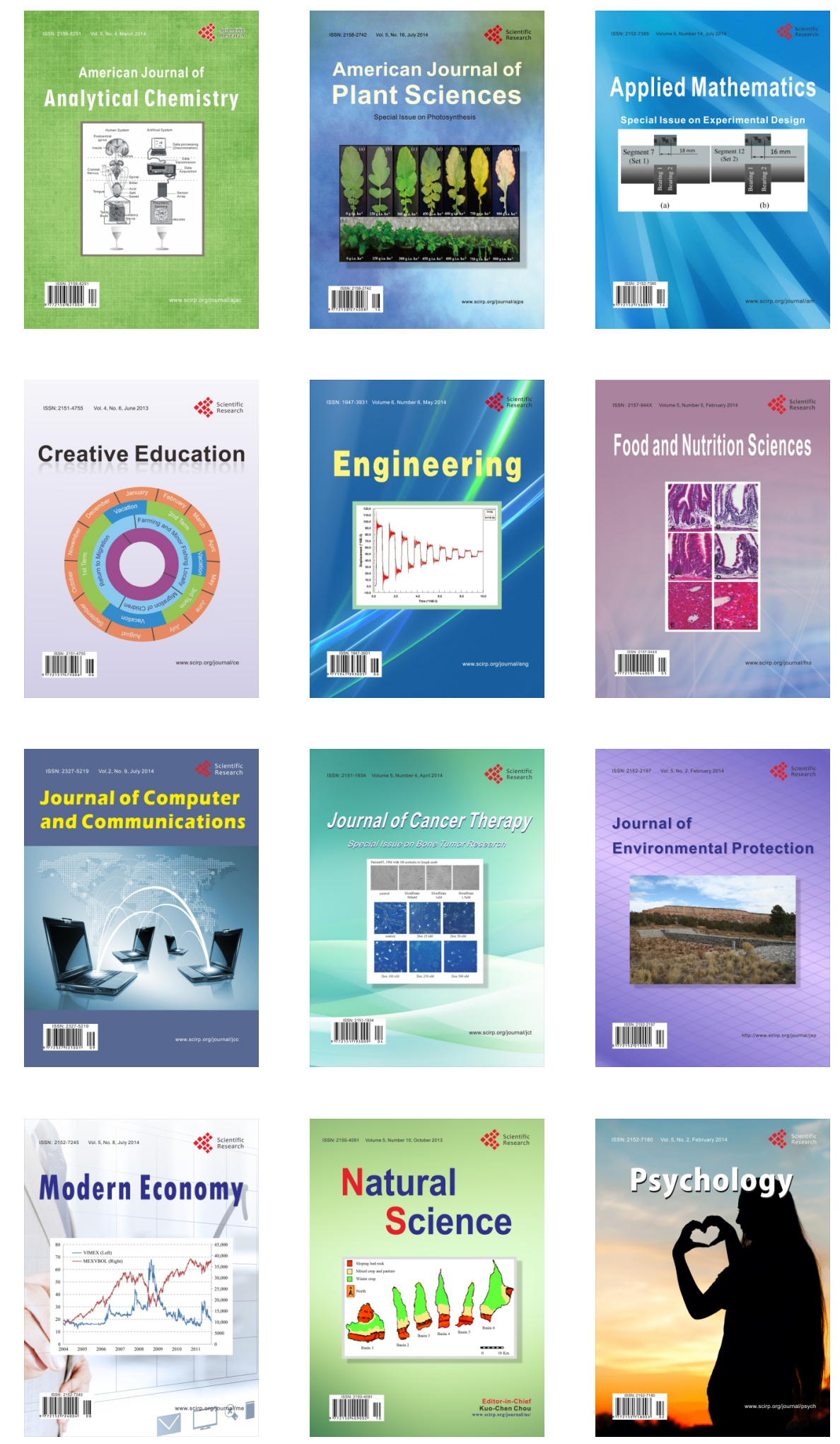